\title{
A III-29 高令者の腹部大動脈溜に対する外科治療の問題点
}

\begin{tabular}{|c|c|c|c|c|c|c|c|}
\hline \multirow[b]{2}{*}{ 池下 } & \multicolumn{7}{|c|}{ 胸部外科, 岸病院* } \\
\hline & 正敏 & 新田 & 隆 & 原田 & 厚 & 佐藤 & 要悟 \\
\hline 家所 & 良夫 & 榊原 & 重泰 & 田中 & 茂夫 & 山手 & \\
\hline & & 庄司 & 佑 & 中條 & 能正* & & \\
\hline
\end{tabular}

近年, 腹部大動脈瘤に対する外科治療成績は向上する とともに, 平均寿命の延びている現在, 高令者に対する 外科治療の機会が増加すると推測される. 現在まで手術 成績, 遠隔成績から高令者であることが手術適応の判断 とはならないことが報告されているが，それでも高令者 に特有な種々の合併症が致命的となることる少なくない. 教室では, 腹部大動脈瘤手術にかかわる諸問題について 検討したので報告する.

\section{対象および方法}

1970 年から 1981 年の期間に手術治療を行った 70 才 以上の腹部大動脈瘤症例 13 例で, 年令分布は $70 \sim 83$ 才, 平均 73.8 才で男女比は 5.5:1 であった. 13 例中 6 例は非破裂性大動脈瘤で待期手術が行われ，7 例は破 裂性大動脈瘤で全例に緊急手術が行われた.この中の 1 例は術中, 胸腹部大動脈瘤と診断され，他の 12 例は腎 下部動脈瘤で腎動脈下で血流遮断が可能であった. 手術 方法は, Y字型人工血管にて置換し, 下腸管膜動脈は全 例結紮切断し, 最低一側の内腸骨動脈の血流は温存する ように努めた。

\section{結果および考察}

手術死亡率については, 非破裂性大動脈瘤では 6 例中 死亡例は無く, 破裂性大動脈瘤では 7 例中 3 例の死亡例 を認め, 死亡率 $42.9 \%$ と極めて高率であった． 死肉と しては, 術中急性心筋梗塞の発生, 破裂による出血性シ ョックから手術室搬送中, 心停止となり心蘇生後手術を 終了したが, 脳死と判定された例, 術中出血のコントロ ールが不可能となった胸腹部大動脈瘤の合計 3 例で, 非 破裂例に対する待期手術に比して, 破裂例に対する緊急 手術の困難性を示した.

術前合併症については, 高血圧例が非破裂例, 破裂例 において，66.7\%，57.1\% と高率に認められ，全体と して多臓器の動脈硬化性疾患の存在を念頭におくべきで あることを示唆した. とくに破裂例に叔いては, 緊急手
術となるので，術前合併症については十分な検索ができ ないことが多く，これらの術前合併症を念頭に打いて術 中術後の管理をする必要があると考える.

術後早期の合併症については, 腸管虚血を疑う症状を 呈した例が多く認められ，非破裂例，破裂例を含めて全 体として，70\% と高率であり，特に腸管出血は 3 例に 認められた．手術方法として内腸骨動脈の血行保存に留 意し，下腸間膜動脈を結禁切断したものの，内腸骨動脈 領域の閉塞性動脈硬化性病変の合併が疑われ，下腸管膜 動脈の血行再建の必要性を考慮しなければならないと考 える、また，一般的に多いとされる術後合併症の腎機能 障害, 肺機能障害は術後管理の向上により発生頻度は多 くなった.

術後早期および遠隔期の死亡率と死因（表 1）につい ては, 非破裂例における脳動脈硬化性疾患による 2 死亡 例がそれぞれ術後 7 年, 8 年の長期生存例で, 術前合併 症として高血圧症, 脳動脈硬化性疾患が認められた。 た，腎機能障害で死亡した 1 例は術後 3 年生存した例で， 術後早期合併症としてやはり腎機能障害を併発していた. これに対し, 破裂例では術後 2 力月半, 3 力月の 2 例の 病院死の他, 脳動脈硬化性疾患により術後 1 年で死亡し た 1 例を含む．死因が人工血管置換術に関連する原因よ りも, 術前術後の一般的高令者に起り得る合併症と関 連があることが特徴的とい壳る。

非破裂例と破裂例の術後生存率をみると，4年生存率

表 1 術後死亡率と死因

\begin{tabular}{|c|c|c|c|}
\hline \multirow[b]{2}{*}{ 死 } & 症 & E 例 & 数 \\
\hline & $\begin{array}{l}\text { 非破裂性 } \\
(\mathrm{n}=6)\end{array}$ & $\begin{array}{c}\text { 破裂性 } \\
(\mathrm{n}=4)\end{array}$ & 合 計 \\
\hline 脳動脈硬化性疶患 & 2 & 1 & 3 \\
\hline 急性心筋梗塞 & & 1 & 1 \\
\hline 腎機能障害 & 1 & & 1 \\
\hline 壊死性胆䔬炎, 肺炎 & & 1 & 1 \\
\hline 術後死亡率 & $(3 / 6) 50 \%$ & $(3 / 4) 75 \%$ & $(6 / 10) 60 \%$ \\
\hline
\end{tabular}


でそれぞれ，83.3\%，25\% であった。この差は，破裂 例に叔ける 2 例の病院死亡考壳られるが，今回の検討飞 より具体的な結論は得られなかった。

\section{結語}

教室で経験した 70 才以上の腹部大動脈瘤に対する外 科治療の検討により, 次の結論を得た。

1）非破裂例に対する待期手術成績は良好で，遠隔死
亡原因は術前合併症としての動脈硬化性疾患が多かった。 したがって，術後の管理により遠隔成績も向上すると考 完られる。

2）破裂例に対する手術成績は不良で，その原因とし て出血によるショック，血腫の進展による手術の困難性， 高令者の術前合併症が考党られた. 早期診断之待期手術 が必要で, 緊急手術時は多臓器の動脈硬化性病変を考慮 して管理を行うことにより成績は向上すると考学る。

\section{A III-30 高令者の腹部大動脈瘤の手術成績}

—之くに術前，術後の合併症を中心に一

\begin{tabular}{|c|c|c|c|c|c|c|c|}
\hline & & & F葉大学 & 第 1 外 & & & \\
\hline 中川 & 康次 & 芝入 & 正雄 & 安野 & 憲一 & 沖本 & 光典 \\
\hline & 政久 & 峯村 & 善保 & 山本 & 和夫 & 北川 & 学代 \\
\hline & 椎原 & 秀茂 & 古川 & 斉 & 奥井 & 勝二 & \\
\hline
\end{tabular}

\section{はじめに}

腹部大動脈瘤は大部分が動脈硬化に起因するため，従 来高令者に多い疾患であるが，近年平均寿命の延長によ り，一層本症の高令化が問題になって来ている，そこて 本症に対する外科治療上，高令者に和将る問題点を，術 前, 術後の合併症を中心検討した。

\section{対 象}

昭和 57 年 12 月までに教室で手術を施行した腹部大 動脈瘤 45 例を，70 才以上の $\mathrm{A}$ 群，70 才未満の $\mathrm{B}$ 群の 2 群にわけて検討した。A群は 15 例. 全例男性, 年令 は70 81 才 (平均 73.5 才) で，全例動脈硬化性であ る. B群は 30 例， 24 例が男性で，年令に $24 \sim 69$ 才 (平均 61.1 才), 解離性 1 , 大動脈炎 1 を除く 28 例が 動脈硬化性であった，手術は全例，大動脈瘤切除，代用 血管置換を行った４４例飞待機手術，B群の 4 例に緊 急手術（3 例は破裂例， 1 例は切迫破裂例）が行われた。

\section{成続}

1. 術前合併症. 胃十二指腸潰場の既往を有するもの が 15 例方り，とくにA群 7 例 (46.5\%) でB群の 8 例 (26. $7 \%$ ) 比し高率であった。中等度以上の 腎機能障 害も A 群 $33.3 \%$ ， B 群 $10.0 \%$ で $\mathrm{A}$ 群に多く認められ
た.しかし B 群の 2 例は, $\mathrm{Ccr} 20 \mathrm{~m} l / \mathrm{min}$ 前後の高度の 慢性腎不全状態にあった。高血圧の合併はA，B群とも 飞高率で亦ったが，肺機能障害，冠動脈疾患は B 群に高 率であった．また両群に 1 例ずつ，慢性 DIC の合併を 認めた。

2. 手術死亡. 緊急手術 4 例中 2 例, 待期手術 41 例 中 2 例 $(4.9 \%)$, 計 4 例を手術で失った。緊急手術例は いずれも B 群で, 破裂例 3 例のうち術前ショック状態に あった 2 例 (66.7\%) は全例死亡した. 待期手術の死亡 は A, B 群とも 1 例ずつで，死亡率は和の沶の $6.7 \%$, 3. $8 \%$ であった。 これらの 2 例はいずれも術前 DIC の 合併を認めた症例である（表 1 ），S．Y．例は，術前検 查中に発見された胃癌に対する胃切除時に，術中，術後 の異常出血があり, 諸検査の結果 DIC 々診断された。 胃癌は進行癌であったが限局性で, 遠隔転移は認めなか った，K，T. 例は術前準備中，注射部位に巨大血腫を発 生し, 同様に DIC と診断された。術前へパリンの静脈 内投与を行い，とくに血小板数の回復を待って手術を施 行した. S.Y.例は術中結腸を損傷し，その縫合不全か ら沉発性腹膜炎，敗血症を併発し術後 13 日に死亡した， 術中出血量は $6.145 \mathrm{~m} l$ と大量であった。 K. T. 例は術 中の止血は困難でなかったが，術直後より無尿となり， 突然心停止して術当日死亡した.

3. 術後合併症 (表 2 ). 術後何 らかの 合併症を発症 